\title{
THE BASICS OF SPECIES AT RISK LEGISLATION IN ALBERTA
}

\author{
SHAUN FLUKER* AND JOCELYN STACEY ${ }^{* *}$
}

This article examines Alberta's Wildlife Act and the federal Species at Risk Act (SARA) to assess the legal protection of endangered species in Alberta. Most of the discussion relates to provisions contained in SARA, as there is comparatively less to discuss under the Wildlife Act. The fact that legal protection for endangered species in Alberta consists primarily of federal statutory rules is unfortunate, as wildlife and its habitat are by and large property of the provincial Crown, and it is a general principle of constitutional law that the federal government cannot in substance legislate over provincial property under the guise of a regulatory scheme. The legal protections in SARA are, thus, for the most part restricted to species found on federal lands and to species that fall under federal legislative powers. This article demonstrates that the Alberta government has chosen to govern species at risk almost entirely by policy and discretionary power. The limited application of federal protections to provincial lands and the absence of meaningful protection in the Wildlife Act leads the authors to conclude that, despite a perception of legal protection for endangered species, such protection does not exist in Alberta.
Cet article examine la Loi sur la faune de l'Alberta et la loi fédérale intitulée Loi sur les espèces en péril dans le but d'évaluer la protection juridique des espèces en danger en Alberta. La plus grande partie de la discussion concerne les dispositions contenues dans la Loi sur les espèces en péril étant donné qu'il y a moins de matière à discussion dans la Loi sur la faune. Le fait que la protection juridique des espèces en péril en Alberta consiste essentiellement en des règles en vertu de lois fédérales est malheureux étant donné que la faune et son habitatreprésentent surtout la propriété de la Couronne provinciale et que c'est un principe général du droit constitutionnel que le gouvernement fédéral ne peut en substance légiférer la propriété provinciale sous l'apparence d'un plan de réglementation. La protection juridique de la Loi sur les espèces en péril se limite donc, pour la plus grande partie, aux espèces que l'on trouve sur les terres fédérales et aux espèces régies par les pouvoirs législatifs fédéraux. Cet article démontre que le gouvernement de l'Alberta a choisi de gouverner les espèces en péril presque entièrement par politique et pouvoir discrétionnaire. L'application limitée des protections fédérales aux terres provinciales et l'absence de réelle protection dans la Loi sur la faune amènent l'auteur à conclure que, malgré la perception d'une protection juridique pour les espèces en péril, une telle protection n'existe pas en Alberta.

\section{TABLE OF Contents}

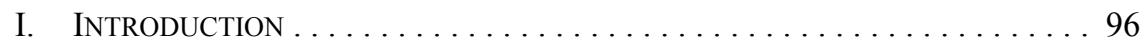

II. Legal Designation of A SPecies AT Risk in Alberta . . . . . . . . . . . 98

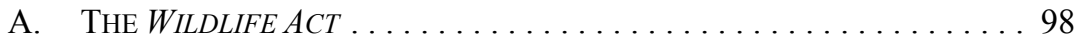

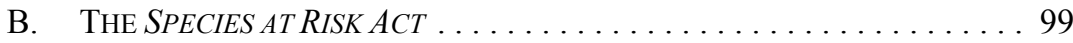

C. Concluding Thoughts on the Listing Process $\ldots . . . . . .104$

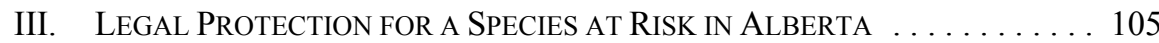

A. THE WILDLIFE ACT . . . . . . . . . . . . . . . . . . 105

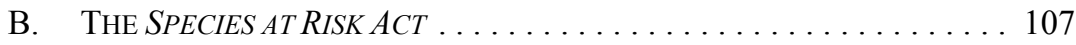

C. Concluding Thoughts on Legal Protection:

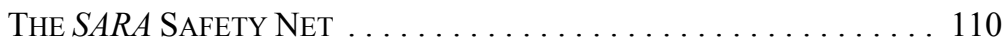

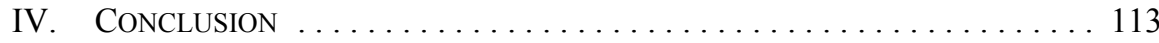

* Assistant Professor, Faculty of Law, University of Calgary. The authors express thanks to the anonymous referees for their constructive feedback on an earlier draft of this article.

** Doctor of Civil Law Candidate, McGill Faculty of Law; LLM (Yale); LLB (Calgary). This author's contribution arose from research conducted while completing her LLB at the University of Calgary. 


\section{INTRODUCTION}

Legal protection of wildlife in Canada dates back over a century to the early days of resource conservation in the late nineteenth century. Wildlife populations fell drastically during this time period, with the invention of the repeating rifle and the construction of transcontinental railways that brought a large number of settlers who cleared the land and relied on wildlife for sustenance. ${ }^{1}$ The decimation of wildlife populations alarmed government officials and sparked the development of resource conservation policies to manage wildlife on public lands. ${ }^{2}$ These policies led to wildlife legislation that contained new rules to manage which, when, where, and how much wildlife could be killed. The federal government also established forest reserves, wildlife sanctuaries, and national parks to assist in the conservation of wildlife. ${ }^{3}$

The rise of environmentalism in the late twentieth century changed the philosophy on wildlife protection from resource conservation to species protection. In 1992, Canada ratified the United Nations Convention on Biological Diversity, ${ }^{4}$ and the federal government thereby committed the nation to this new philosophy and the goal of conserving biodiversity within its borders. This commitment included the enactment of legislation to protect threatened species, as well as to develop and implement policy to maintain or restore viable populations of species in their natural habitat..$^{5}$ The federal and provincial governments subsequently entered into the National Accord for the Protection of Species at Risk. ${ }^{6}$ The stated purpose of the National Accord is to prevent species in Canada from becoming extinct as a consequence of human activities. All signatories to the National Accord agreed to establish legislation and policy for the effective protection of endangered species. ${ }^{7}$

These commitments to species protection and restoration are predicated on a deeper understanding of the ecological structure and process that sustains life on earth, and the corresponding need to respect the contribution that all species make in this regard. These commitments are also based, in part, on an ethic that holds that all species have inherent value as an encoded life structure and process, and that all species, thus, have the moral right to exist apart from their usefulness to humans. ${ }^{8}$ These ecological and ethical considerations underlying species at risk legislation have resulted in a more systematic method of protecting species (commonly referred to as a listing process) and stricter prohibitions against harming species and their habitat than that of earlier wildlife laws that protected wildlife as a resource.

See generally Janet Foster, Working for Wildlife: The Beginning of Preservation in Canada (Toronto: University of Toronto Press, 1978); Tina Loo, States of Nature: Conserving Canada's Wildlife in the Twentieth Century (Vancouver: UBC Press, 2006).

Ibid.

Ibid.

Convention on Biological Diversity, 5 June 1992, 1760 UNTS 79 (entered into force 29 December 1993).

Ibid, art 8(k).

6 Agreed to in principle October 1996, online: Government of Canada <http://www.sararegistry.gc.ca/ approach/strategy/Accord e.pdf> [National Accord].

The terms "species at risk" and "endangered species" are used interchangeably in this article, except where the context dictates otherwise.

8 See generally Holmes Rolston III, "Duties to Endangered Species" in Robert Elliot, ed, Environmental Ethics (Oxford: Oxford University Press, 1995) 60. 
Components of species at risk legislation typically include: (1) status designations; (2) a process for designating species at risk (a listing process); and (3) measures to recover and protect species at risk and their habitat. The manner in which these components are implemented varies significantly across Canadian jurisdictions. Some jurisdictions empower scientific committees to administer the listing process, while other jurisdictions give this power to Cabinet or a minister. One implication of this statutory design concerns the extent to which listing decisions are based on science or politics, with fewer jurisdictions giving scientists decision-making power. ${ }^{9}$ The listing process is of central importance because legislation only offers protection to listed species. Some jurisdictions offer minimal legal protection that does not even prohibit the killing of an endangered animal, while other jurisdictions legally prohibit any harm to an endangered animal and its critical habitat.

One-half of Canadian jurisdictions have enacted dedicated legislation to provide legal protection for species at risk and their habitats. These jurisdictions include Canada, Manitoba, Ontario, Quebec, Nova Scotia, the Northwest Territories, and New Brunswick. Parliament enacted the federal Species at Risk $A c t^{10}$ in 2002. The overall purpose of the legislation is

to prevent wildlife species from being extirpated or becoming extinct, to provide for the recovery of wildlife species that are extirpated, endangered or threatened as a result of human activity and to manage species of special concern to prevent them from becoming endangered or threatened. ${ }^{11}$

The province of Alberta is one of seven Canadian jurisdictions that have not enacted dedicated endangered species legislation. The other jurisdictions include British Columbia, Saskatchewan, Prince Edward Island, Newfoundland, Nunavut, and the Yukon. To comply with its commitment as a signatory to the National Accord, the Alberta government amended the Wildlife Act $^{12}$ in 1996, adding rules for the designation and protection of endangered species in Alberta.

This article examines the provisions of the Wildlife Act and SARA that govern species at risk protection in Alberta. The analysis traces the primary components of species at risk legislation, commencing with the listing process and followed by protection measures. Most of the discussion relates to $S A R A$, simply because there is comparatively less to discuss under the Wildlife Act. The fact that legal protection for species at risk in Alberta consists primarily of federal statutory rules is unfortunate, as wildlife and its habitat are by and large property of the provincial Crown, and it is a general principle of constitutional law that the federal government cannot, in substance, legislate over provincial property under the guise of a regulatory scheme. The legal protections in $S A R A$ are thus, for the most part, restricted to species found on federal lands, such as national parks, and to species that fall under federal legislative powers, such as fish and migratory birds. The constraints in $S A R A$ add a measure of complexity to assessing exactly how the law protects species at risk in Alberta.

Stewart Elgie, "Statutory Structure and Species Survival: How Constraints on Cabinet Discretion Affect Endangered Species Listing Outcomes"(2008) 19:1 J Envtl L \& Prac 1 at 12-13.

SC 2002, c $29[$ SARA].

Ibid, $\mathrm{s} 6$.

RSA $2000, \mathrm{c} \mathrm{W}-10$. 
The analysis in this article demonstrates that the Alberta government has chosen to govern endangered species almost entirely by policy and the use of discretionary power. The limited application of $S A R A$ protections to provincial lands combined with the absence of meaningful protection in the Wildlife Act leads to the conclusion that the legislative framework is just smoke and mirrors: there is a perception of legal protection for endangered species that does not actually exist in Alberta.

\section{Legal Designation of a Species at Risk in Alberta}

\section{A. THE WILDLIFE ACT}

The Wildlife Act does not contain a substantive definition of an endangered species, but rather section 1(1) defines an endangered species as a kind of endangered animal or plant as prescribed in the Wildlife Regulation. ${ }^{13}$ Section 4(1) of the Wildlife Regulation prescribes endangered species as those endangered animals, invertebrates, algae, fungi, and plants listed in Schedule 6 of the regulation. In practice, the provincial Minister of Environment and Sustainable Resource Development legally designates a species as endangered by enacting a regulation that adds it to Schedule 6. An endangered species under the Wildlife Act is, thus, a species that the Minister prescribes as such. Notably, the Wildlife Act only makes reference to the "endangered" designation, while government policy references the designations of "endangered," "threatened," and "special concern."14

Section 6(1) of the Wildlife Act requires the Minister to establish and maintain an Endangered Species Conservation Committee (ESCC) which functions as an advisory body and makes recommendations to the Minister on matters pertaining to endangered species, including: (1) which species should be listed as endangered, and (2) the preparation and implementation of recovery plans for endangered species. Section 6(2) of the Wildlife Act requires the ESCC to appoint a subcommittee of scientists to assess the status of species and report to the committee as a whole on whether the species should be listed as endangered. The activities of the ESCC are posted on the website of Alberta Environment and Sustainable Resource Development. ${ }^{15}$

The composition and functioning of the ESCC is almost wholly within the discretion of the Minister or the ESCC itself. There are several reasons why this discretionary structure is of concern from a species protection perspective. First, there is no legal requirement that members of the ESCC have any qualifications related to wildlife biology or ecology. While in practice ESCC members may be so qualified, there is no legal process by which to ensure this. Second, there is no legal process to direct how, when, and on what basis the ESCC

13 Alta Reg 143/1997.

14 See Alberta Sustainable Resource Development, Fish and Wildlife Division, Alberta's Strategy for the Management of Species at Risk (2009-2014) (Edmonton: Alberta Sustainable Resource Development, 2008), online: Alberta Sustainable Resource Development <http://srd.alberta.ca/FishWildlife/Species AtRisk/AlbertasSpeciesAtRiskStrategy/documents/Alberta'sStrategyForManagementOfSpeciesAt Risk2009-14.pdf> [Strategy for the Management of Species at Risk].

15 See "Background Documents," online: Alberta Environment and Sustainable Resource Development $<$ http://www.srd.alberta.ca/ FishWildlife/SpeciesAtRisk/LegalDesignationOfSpeciesAtRisk/Albertas SpeciesAtRisk/BackgroundDocuments.aspx $>$. 
decides to assess the status of a species in Alberta. Third, there is no statutory obligation on the Minister to respond to ESCC status recommendations.

The absence of any legal process in listing decisions under the Wildlife Act translates into unpredictable and non-transparent executive decision-making. The case of the grizzly bear species in Alberta provides a good example. There are many reasons besides the rule of law for why the Alberta government would take steps to restore and ensure the long-term viability of grizzly bears in Alberta. We will set out two here. First, the government's wildlife experts believe the grizzly bear is a "keystone" or "umbrella" species. ${ }^{16}$ This means a viable population of grizzly bears on the landscape is a reliable indicator of ecological integrity for the landscape as a whole. ${ }^{17}$ In other words, the government achieves its mandate of sustainable resource development by ensuring such development does not adversely affect the grizzly bear population and its habitat. Second, the grizzly bear is, perhaps, one of the last vestiges of the disappearing Canadian wilderness and the enrichment it provides. Author Jeff Gailus recounts the value in sighting a grizzly bear in the wild: "Like having a child, encountering a grizzly bear in the wild is something you can anticipate with the common sense of the conscious mind, but when it finally arrives, you discover one of the few experiences that actually surpass what you had imagined." ${ }^{\prime 18}$ In short, Alberta is a lesser place without a self-sustaining population of grizzly bears on the land.

Over the last decade, the Alberta government has expressed significant concern for the viability of the grizzly bear species in Alberta. The ESCC recommended that the Minister list the species as threatened in 2002 and renewed this recommendation in early $2010 .{ }^{19}$ The overall message from the ESCC is that grizzly bear numbers are in decline because of increasing human activities in what is left of the grizzly bear habitat in Alberta. ${ }^{20}$ In March 2008, six years after the initial ESCC recommendation for a "threatened" designation, the department of Alberta Sustainable Resource Development, Fish and Wildlife Division issued a plan for the recovery of the grizzly bear species. ${ }^{21}$ Remarkably, this recovery plan was developed for the species before it was legally designated as at risk. Then, to the surprise of many observers, the Minister enacted the Wildlife (Endangered Animal, 2010) Amendment Regulation $^{22}$ in June 2010 to add the grizzly bear species to Schedule 6 of the Wildlife Regulation as an endangered species in Alberta.

\section{B. THe SPECIES AT RISK ACT}

The SARA listing process applies to all wildlife species in Canada, and, thus, can overlap with listings under the Wildlife Act. For example, the swift fox, sage grouse, and piping

Alberta Grizzly Bear Recovery Team, Alberta Grizzly Bear Recovery Plan 2008 - 2013 (Edmonton: Alberta Sustainable Resource Development, 2008) at 2 [Grizzly Bear Recovery Plan].

Ibid.

Jeff Gailus, The Grizzly Manifesto: In Defence of the Great Bear (Victoria, BC: Rocky Mountain Books, 2010) at 22 .

Marco Festa-Bianchet, Status of the Grizzly Bear (Ursus arctos) in Alberta: Update 2010 (Edmonton: Alberta Sustainable Resource Development and Alberta Conservation Assocition, 2010), online:Alberta Environment and Sustainable Development $<$ http://www.srd.alberta.ca/BiodiversityStewardship/Species AtRisk/DetailedStatus/documents/Status-GrizzlyBear-inAlberta-Feb2010.pdf>.

Ibid at 22, 27.

Grizzly Bear Recovery Plan, supra note 16. Alta Reg 86/2010. 
plover species are listed as endangered under both statutes. In contrast with the provincial regime, however, a $S A R A$ listing involves legal process. The process under $S A R A$ involves several layers of decision-making by three primary actors: (1) the Committee on the Status of Endangered Wildlife in Canada (COSEWIC); (2) the federal Minister of the Environment; and (3) the Governor in Council. The role of each in the listing process under the legislation is discussed in turn. While not a species located in Alberta, this discussion employs the case of the polar bear species listing process to demonstrate the relative transparency of the $S A R A$ listing process as compared to the listing process under the Wildlife Act.

$S A R A$ defines three status designations for species at risk: (1) endangered species, meaning a "wildlife species that is facing imminent extirpation or extinction"; (2) threatened species, meaning a "wildlife species that is likely to become an endangered species if nothing is done to reverse the factors leading to its extirpation or extinction"; and (3) species of special concern, meaning a "wildlife species that may become a threatened or an endangered species because of a combination of biological characteristics and identified threats." 23

The endangered, threatened, and special concern designations form a continuum based on the seriousness of the threat of extinction, with endangered species facing the most immediate threat and those species of special concern facing the least. ${ }^{24}$

COSEWIC is a committee of scientists and other individuals with particular expertise in assessing the welfare of wildlife species. ${ }^{25}$ Section 16(2) of SARA requires members of COSEWIC to have expertise in wildlife conservation. COSEWIC's primary responsibility under $S A R A$ is to assess the status of species and to classify them into one of the designation categories. ${ }^{26}$ COSEWIC has the authority to decide when to assess the status of a species; however any person may petition COSEWIC to conduct an assessment of a species. ${ }^{27}$ COSEWIC makes its assessment decision based on a species status report, prepared either under the direction of COSEWIC or provided to COSEWIC by a petitioner. ${ }^{28}$ COSEWIC must complete its assessment of a species, with reasons for its conclusion, within one year of receiving a status report. ${ }^{29}$

The analysis in this article focuses exclusively on the designations of endangered or threatened.

COSEWIC was initially formed in 1977, predating the enactment of SARA by 25 years. The COSEWIC website provides a comprehensive description of the committee and its functions in relation to species at risk in Canada. See COSEWIC - Committee on the Status of Endangered Wildlife in Canada, online: Government of Canada $<$ http://www.cosewic.gc.ca>.

26 SARA, supra note 10, s 15(1).

27 Ibid, ss $15(1)$ (b), 22(1). The process by which a person may petition COSEWIC is not set out in $S A R A$, but section 22(2) provides the Minister with the authority to enact regulations that prescribe this process. While there are currently no such regulations, COSEWIC has issued its own guidelines on the petition process (see COSEWIC, "Applications for Wildlife Species Assessment and Unsolicited Wildlife Species Status Reports" (November 2011), online: COSEWIC <http://www.cosewic.gc.ca/html Documents/appendixf9 e.html $>$ ). The legal status of this COSEWIC procedure is, at best, uncertain given that the Act specifically empowers only the Minister in this regard.

28 SARA, ibid ss 15(2), 21(1). The financial and other resources dedicated to research necessary to prepare a status report almost certainly influence the assessment decision, but there is no mention of available resources in the Act.

29 Ibid, s 23(1). Further, if the assessment was conducted as the result of an application, COSEWIC must also notify the applicant of the conclusion and reasons (ibid, s 23(2)). 
The COSEWIC assessment on the status of a species must be forwarded to the Minister and placed on the public registry maintained under $S A R A .{ }^{30}$ Section $25(3)$ requires the Minister to respond to the COSEWIC assessment within 90 days, and specifically states:

On receiving a copy of an assessment of the status of a wildlife species from COSEWIC under subsection

(1), the Minister must, within 90 days, include in the public registry a report on how the Minister intends to respond to the assessment and, to the extent possible, provide time lines for action.

There is some uncertainty as to when this 90 day period begins to run. The view of the Minister is that it does not begin until the Minister has formally acknowledged receipt of the COSEWIC assessment. ${ }^{31}$ In practice, the Minister does not issue an acknowledgement upon actual receipt of the COSEWIC assessment, but rather does so sometime later. Accordingly, the Minister's response to a COSEWIC assessment can take months, if not years, to be issued, depending upon when the formal acknowledgement is issued. For example, COSEWIC issued an assessment on the polar bear species in April 2008 which recommended a species of special concern designation. ${ }^{32}$ The Minister acknowledged receipt of the assessment in November 2008 and indicated an intention to recommend that the Governor in Council list the polar bear as a species of special concern, but only after consultations with numerous provincial and territorial governments, wildlife management agencies, and Aboriginal peoples. Some argue that the Minister's practice contravenes Parliament's intention that the Minister consider the COSEWIC assessment, consult necessary departments on the matter, and decide on a listing recommendation in a timely manner. $^{33}$

There is also some uncertainty over what section 25(3) requires of the Minister. In practice, the Minister sometimes responds that the COSEWIC assessment and its listing recommendation will be forwarded to the Governor in Council within 90 days, but in other instances the Minister only sets out the process to be followed in making the listing recommendation that will eventually be forwarded to the Governor in Council. ${ }^{34}$ In cases where the Minister's section 25(3) response only sets out a process for making a listing recommendation, it can take the Minister a year or longer to provide a listing recommendation to the Governor in Council after COSEWIC completes its species assessment. For example, in the case of the polar bear species, the Governor in Council acknowledged receipt of the Minister's listing recommendation and the COSEWIC

$30 \quad$ Ibid, s 25(1). Section 120 of SARA requires the Minister to maintain a public registry for documentation. The public registry is located online: see Government of Canada, "Species at Risk Public Registry," online: Government of Canada $<$ http://www.sararegistry.gc.ca $>$.

31 See Office of the Auditor General of Canada, "The Species at Risk Act - Petition no 121" (30 June 2004), online: Office of the Auditor General of Canada <http://www.oag-bvg.gc.ca/internet/English/ pet_121_e 28844.html> [Petition no 121].

32 See COSEWIC, COSEWIC Assessment and Update Status Report on the Polar Bear Ursus martimus in Canada (Ottawa: Environment Canada, 2008), online: Government of Canada <http://www. sararegistry.gc.ca/virtual_sara/files/cosewic/sr_polar_bear_0808_e.pdf> [COSEWIC 2008 Polar Bear Assessment].

33 For example, this argument was made by the petitioner in Rounthwaite $v$ Canada (Minister of the Environment), 2007 FC 921, 13 CELR (3d) 313 [Rounthwaite]. In 2004 the Environmental Defence Fund filed a petition with the federal Auditor General seeking an explanation from the Minister for the lengthy delays in the listing process. See Petition no 121, supra note 31.

34 The variability in the Minister's section 25(3) response is observed by surveying the SARA public registry. See "Listing — Listing Process," online: Government of Canada <http://www.sararegistry. gc.ca/sar/listing/default_e.cfm>. 
assessment in February 2011. In the case of this species, nearly three years passed from the completion of the 2008 COSEWIC assessment to its receipt by the Governor in Council.

Section 27 of $S A R A$ empowers the Governor in Council with the authority to list (or delist) a species as endangered, threatened, or of special concern by amending Schedule 1 of $S A R A$ with an Order in Council. Schedule 1 sets out the species at risk designated under the legislation in the various categories. Section 27(1.1) provides the Governor in Council, after reviewing the COSEWIC assessment and the Minister's listing recommendation, with the authority to decide on the listing in one of three ways: (1) accept the assessment and list the species; (2) decide not to list the species; or (3) refer the matter back to COSEWIC for further consideration. ${ }^{35}$ Listing authority is exclusive to the Governor in Council, with the sole exception being in cases where the Governor in Council does not issue its section 27(1.1) course of action decision within nine months of receiving the COSEWIC assessment. In those instances, section 27(3) requires the Minister to amend Schedule 1 in accordance with the COSEWIC assessment. For ease of reference, section 27 of $S A R A$ reads as follows:

(1) The Governor in Council may, on the recommendation of the Minister, by order amend the List in accordance with subsections (1.1) and (1.2) by adding a wildlife species, by reclassifying a listed wildlife species or by removing a listed wildlife species, and the Minister may, by order, amend the List in a similar fashion in accordance with subsection (3).

(1.1) Subject to subsection (3), the Governor in Council, within nine months after receiving an assessment of the status of a species by COSEWIC, may review that assessment and may, on the recommendation of the Minister,

(a) accept the assessment and add the species to the List;

(b) decide not to add the species to the List; or

(c) refer the matter back to COSEWIC for further information or consideration.

(1.2) Where the Governor in Council takes a course of action under paragraph (1.1)(b) or $(c)$, the Minister shall, after the approval of the Governor in Council, include a statement in the public registry setting out the reasons.

(2) Before making a recommendation in respect of a wildlife species or a species at risk, the Minister must

(a) take into account the assessment of COSEWIC in respect of the species;

(b) consult the competent minister or ministers; and

(c) if the species is found in an area in respect of which a wildlife management board is authorized by a land claims agreement to perform functions in respect of a wildlife species, consult the wildlife management board.

35 Where the Governor in Council does not accept the assessment and list the species, section 27(1.2) requires the Minister to provide reasons for the decision. 
(3) Where the Governor in Council has not taken a course of action under subsection (1.1) within nine months after receiving an assessment of the status of a species by COSEWIC, the Minister shall, by order, amend the List in accordance with COSEWIC's assessment.

A literal reading of section 27 suggests that the Governor in Council enjoys nearly absolute discretion in deciding whether to list a species under $S A R A$, with the only constraints on this authority being the nine month period in which the Governor in Council must issue a course of action decision and the obligation to provide reasons for not listing

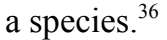

Where the Governor in Council declines to list a species under section 27, the Minister routinely cites socio-economic factors as justification pursuant to section $27(1.2) \cdot{ }^{37}$ Federal policy is to conduct a cost/benefit assessment as part of the listing decision-making process to determine the relative costs and benefits of adding or not adding a particular species to Schedule $1 .^{38} \mathrm{~A}$ recent study of listing decisions confirms that species with commercial economic value as a harvested resource are less likely to be listed by the Governor in Council under SARA. ${ }^{39}$

Returning again to the case of the polar bear for an illustration of the dynamics involved in a listing process under $S A R A$, COSEWIC has assessed the status of the polar bear five times since $1986 .^{40}$ The 1986 assessment concluded that the polar bear was not at risk, but every subsequent COSEWIC assessment since then (in 1991, 1999, 2002, and 2008) has designated the polar bear as a species of special concern. In response to the 2002 assessment, and on the Minister's recommendation not to list, the Governor in Council declined to add the polar bear to Schedule 1 in 2005. At that time, the Governor in Council referred the polar bear assessment back to COSEWIC pursuant to section 27(1.1). ${ }^{41}$ In May 2010, the Government of Nunavut announced that it did not support the 2008 COSEWIC assessment of special concern, on the view that the polar bear population in Nunavut was not in decline and that the species would adapt to climate change. ${ }^{42}$ In October 2010, Environment Canada announced funding for research into the socio-economic value of polar bears in Canada. ${ }^{43}$ In

36 The COSEWIC assessment has no legal effect, except where the nine month period has elapsed and section 27(3) requires the Minister to list a species in accordance with the COSEWIC assessment. This was a major source of contention during the legislative process, with species advocates calling for a science-based listing decision in which listing under $S A R A$ would flow directly from the COSEWIC assessment. See e.g. Elgie, supra note 9 at 3-6.

37 For a recent example, see Order Giving Notice of Decisions Not to Add Certain Species to the List of Endangered Species, SI/2010-14, (2010) C Gaz II, 385.

38 Environment Canada, Consultation on Amending the List of Species under the Species At Risk Act: Terrestrial Species (Ottawa: Environment Canada, 2006) at 2, online: Government of Canada $<$ http:// www.sararegistry.gc.ca/virtual_sara/files/public/cd_specieslisting_ii_1206_e.pdf>. See also Arne O Mooers et al, "Science, Policy, and Species at Risk in Canada" (2010) 60:10 BioScience 843 at 846; Petition no 121, supra note 31 .

39 C Scott Findlay et al, "Species Listing under Canada's Species at Risk Act" (2009) 23:6 Conservation Biology 1609. See also Jennifer L Dawe \& Barbara Neis, "Species at Risk in Canada: Lessons Learned from the Listing of Three Species of Wolfish" (2012) 36 Marine Policy 405.

$40 \quad$ See COSEWIC 2008 Polar Bear Assessment, supra note 32 at iii.

41 Order Giving Notice of Decisions Not to Add Certain Species to the List of Endangered Species, SI/2005-2, (2005) C Gaz II, 113; Order Giving Notice of Decisions Not to Add Certain Species to the List of Endangered Species, SI/2005-72, (2005) C Gaz II, 1797.

42 Government of Nunavut, News Release, "Minister of Environment: Polar Bear Not an At-Risk Species" (28 May 2010), online: Government of Nunavut <http://www.gov.nu.ca/news/2010/may/may28.pdf>. Steve Rennie, "Feds studying economic benefits of polar bears," The Globe and Mail (6 October 2010), online: The Globe and Mail<http://www.theglobeandmail.com/news/politics/feds-studying-economicbenefit-of-polar-bears/article1744680/>. 
February 2011, the Governor in Council finally acknowledged receipt of the 2008 COSEWIC assessment and the Minister's recommendation of a species of special concern listing. ${ }^{44}$ In accordance with the nine month deadline set by section 27 , the Governor in Council accepted the COSEWIC recommendation in October 2011 and decided to list the polar bear as a species of special concern. ${ }^{45}$

$S A R A$ also includes an emergency listing process whereby any person who believes there is an imminent threat to the survival of a wildlife species may petition COSEWIC to perform an assessment of the threat. ${ }^{46}$ The COSEWIC assessment is forwarded to the Minister, who then forms an opinion as to whether or not there is an imminent threat to the species. If the Minister forms the opinion that there is an imminent threat to the survival of the species, section 29(1) of SARA requires the Minister to recommend to the Governor in Council that the species be listed as an endangered species.

In Rounthwaite, the petitioner sought a judicial order to compel the Minister to form an opinion under section 29(1) as to whether there was an imminent threat to the survival of the Sakinaw Lake sockeye salmon species. ${ }^{47}$ COSEWIC had recommended that the Sakinaw sockeye be listed as an endangered species in October 2002, due to a drastic reduction in adult numbers returning to spawn. ${ }^{48}$ In 2004, the Minister recommended that the Governor in Council not list the Sakinaw sockeye, citing socio-economic concerns for the commercial fishing industry. ${ }^{49}$ At the petitioner's request, COSEWIC conducted an emergency status assessment under section 28 for the Sakinaw sockeye in 2006 and concluded the species faced an imminent threat to its survival. COSEWIC reiterated its recommendation to the Minister that the Sakinaw sockeye be listed as an endangered species. ${ }^{50}$ Prior to the judicial review hearing, the Minister forwarded a recommendation to the Governor in Council that it list the Sakinaw sockeye as an endangered species. ${ }^{51}$ The Federal Court dismissed the petitioner's application for a judicial order as moot. ${ }^{52}$

\section{Concluding Thoughts on the Listing Process}

There is no legal process by which a species becomes listed as endangered under the Wildlife Act. The legislation contains no rules on species listing. The most detailed account of the listing process is contained in the ESCC reports posted to the Alberta Sustainable Resource Development website, the most recent of which is dated June $2006 .{ }^{53}$ The Minister has no legal obligation to respond to an ESCC listing recommendation, to accept the recommendation, or to provide reasons for a listing decision. The listing process under the Wildlife Act is, therefore, non-transparent and completely discretionary.

Order Acknowledging Receipt of Assessment Done Pursuant to Subsection 23(1) of the Act, SI/2011-11 (2011) C Gaz II, 430.

Order Amending Schedule 1 to the Species at Risk Act, SOR/2011-233 (2011) C Gaz II, 2282.

SARA, supra note 10, s 28(1).

See Rounthwaite, supra note 33. For a more detailed account of the petitioner's claim, see Ian Rounthwaite, 'Saving the Sakinaw Sockeye" (2006) 15:1 Green Notes 6.

Rounthwaite, ibid at para 5.

Ibid at para 6-7.

Ibid at para 11 .

Ibid at para 3 .

Ibid at paras 25-27.

See "Background Documents," supra note 15. 
The listing process under $S A R A$ is far more transparent and less discretionary. Relevant listing documents are posted to a public registry which provides the ability to track the listing process for a species from its initial COSEWIC status assessment to the Governor in Council listing decision. There are mandatory timelines that govern the listing process, providing some certainty on when to expect a listing decision. Also, where the Governor in Council decides not to list a species that COSEWIC recommends for listing, the Minister must provide an explanation.

The application of the $S A R A$ listing process to Alberta provides the transparency and predictability that is missing in the Wildlife Act. However, a SARA listing for most species in Alberta does not result in legal protection. For this, the Wildlife Act is the primary governing law.

\section{Legal Protection for a Species at Risk in Alberta}

\section{A. THE WILDLIFE ACT}

The Wildlife Act provides minimal legal protection to an endangered species. The legislation does not include protective measures commonly included in species at risk legislation. There is no direct prohibition against taking (or killing) an individual member of an endangered species. There is no legal obligation to prepare a recovery plan for an endangered species. There is also no protection for the critical habitat of an endangered species. These observations place considerable doubt on any claim that provisions in the Wildlife Act satisfy Alberta's obligation under the National Accord to legislate effective protection for species at risk.

The legal protection afforded under the Wildlife Act is essentially limited to the section $36(1)$ prohibition against wilfully molesting, disturbing, or destroying a house, nest, or den of an endangered animal listed in Schedule 6 of the Wildlife Regulation. ${ }^{54}$ The focus of this protection is on the individual animal rather than the species or population. Moreover, the section only protects against wilful harm to a residence.

The Wildlife Act does not prohibit the taking of an individual member of an endangered species. However, the legislation does indirectly address the taking of an animal in its regulation of hunting. Section 1(1) of the Act includes the act of wilfully killing in the definition of "hunt," and sections 24(1) and 25(1) prohibit hunting without authorization. However, there is nothing particular to an endangered animal in this prohibition, except, perhaps, by an implicit reading that the Minister would not declare an open season for hunting an endangered species or otherwise authorize the hunt of an endangered animal. Moreover, this hunting prohibition does not address an incidental kill where, for example, an endangered animal is taken as a result of resource development activities. Nor does the hunting prohibition offer any protection for an endangered plant. There is no prohibition in the Wildlife Act against killing a member of an endangered plant species.

54 Section 36(1) of the Wildlife Act refers to the den of "prescribed" wildlife. Section 96(a)(i) of the Wildlife Regulation includes an endangered animal as prescribed wildlife for the purpose of section 36(1). Section 86(1) of the Wildlife Act makes it an offence to contravene section 36(1). 
There is no legal obligation on the Minister under the Wildlife Act to prepare or implement a recovery plan for a listed endangered species. Nor is there any legal requirement as to what a recovery plan must include if such a plan is prepared by the Minister. Section 6(3) of the Wildlife Act states that a recovery plan may include the identification of critical habitat, but the legislation does not require it.

There is no critical habitat protection for an endangered species under the Wildlife Act. Section 103(1)(b) of the Act empowers the Minister to designate a wildlife sanctuary or a habitat conservation area, but neither designation provides specific legal protection for the habitat of species at risk. ${ }^{55}$ Hunting is permitted in both areas with the necessary approvals. ${ }^{56}$ There is one designated wildlife sanctuary and five habitat conservation areas in the province. $^{57}$

The plight of endangered boreal caribou populations in northern Alberta is a prime example of the non-existent legal protection for species at risk under the Wildlife Act. The boreal caribou species has been listed as a threatened species under the Wildlife Act since 1987, but the species still awaits any meaningful legal protection in Alberta almost 25 years since being listed. ${ }^{58}$ The Alberta government produced a recovery plan for the species in 2004 with many recommendations on the actions needed to restore a sustainable caribou population in Alberta. ${ }^{59}$ Notably, the Alberta government did not accept the recommendation of its own experts for a moratorium on further resource dispositions in caribou habitat ranges. ${ }^{60}$ A quick glance at the location of the caribou habitat in northeastern Alberta suggests the reason for this - the caribou habitat overlaps with lands subject to oil sands development. ${ }^{61}$

The most significant shortcoming of the Wildlife Act as species at risk legislation is the absence of mandatory recovery planning and critical habitat protections. The Alberta government has, instead, filled this gap with policy. In relation to recovery initiatives for endangered species, the Alberta species at risk strategy states that a recovery plan must be prepared. ${ }^{62}$ The strategy further states that the recovery plan contain three elements: (1) a summary of the current biological status of the species and an evaluation of the factors which have contributed to its decline; (2) a strategy indicating recovery goals and the strategies necessary to mitigate limiting factors and maintain or recover populations; and (3) an action plan that lists the specific activities that will be implemented to achieve the goals of the recovery program. ${ }^{63}$

Section 96(c) of the Wildlife Regulation includes all wildlife in a wildlife sanctuary as "prescribed wildlife" for the purposes of the protection set out in section 36(1) of the Wildlife Act.

Wildlife Regulation, supra note 13, ss 99, 102.

Ibid, Schedules 11, 12. The wildlife sanctuary is the Sheep River Wildlife Sanctuary west of Calgary.

One of the habitat conservation areas is the Ann and Sandy Cross Conservation Area west of Calgary. Deborah Cichowski, Status of the Woodland Caribou (Rangifer tarandus caribou) in Alberta: Update 2010 (Edmonton: Alberta Environment and Sustainable Resource Development and Alberta Conservation Association, 2010) at 1, online: Alberta Sustainable Resource Development $<\mathrm{http}: / / \mathrm{www}$. srd.alberta.ca/FishWildlife/SpeciesAtRisk/DetailedStatus/Mammals/documents/StatusWoodlandCaribou-inAlberta-Jul-2010.pdf>.

Ibid at 65-66.

Ibid.

Ibid at 3 .

Strategy for the Management of Species at Risk, supra note 14 at 6, 9-10. Ibid at 9 . 
The Alberta species at risk strategy does not even mention the term "critical habitat," let alone discuss its protection. Alberta recovery plans that identify critical habitat suggest policy mechanisms for habitat protection. For example, the piping plover recovery plan identifies the shoreline of 13 Alberta lakes as critical habitat for the endangered migratory bird and discusses the use of a protective notation and other management initiatives for protection. ${ }^{64} \mathrm{~A}$ "protective notation" is a policy designation used by the Alberta government to set management guidelines for certain public lands. ${ }^{65}$ Another policy mechanism for habitat protection is the imposition of relevant terms or conditions by Alberta Sustainable Resource Development on a public lands disposition issued under section 20 of the Public Lands Act. ${ }^{66}$ For example, the holder of a surface lease could be required to transplant endangered plants, avoid nesting areas, or use existing access corridors to mitigate the impacts of resource development activity in known habitat for endangered species. One possibility for legal protection outside of the Wildlife Act is the prohibition against damaging public lands as set out in section 54(1) of the Public Lands Act. However, this prohibition is of limited application as it does not apply to an activity which is authorized under provincial legislation. ${ }^{67}$

\section{B. THE SPECIES AT RISK ACT}

$S A R A$ provides legal protection to species listed under the legislation as endangered or threatened. Such protection includes prohibitions against killing an individual of the species, damaging the residence of an individual, or destroying critical habitat for the species. ${ }^{68} S A R A$ makes it an offence for a person to contravene these prohibitions, with penalties up to $\$ 1$ million or five years imprisonment. ${ }^{69}$ This protection generally applies only to: (1) fish or a marine plant as defined in the Fisheries $A c t^{70}$ (hereinafter referred to as fish); (2) a migratory bird covered by the Migratory Birds Convention Act, $1994^{71}$ (hereinafter referred to as a migratory bird); and (3) any wildlife species located on federal lands. Examples of relevant federal lands in Alberta include a national park designated under the Canada National Parks Act, ${ }^{72}$ a national wildlife area designated under the Canada Wildlife Act, ${ }^{73}$ and a migratory bird sanctuary designated under the Migratory Birds Convention Act, 1994. SARA protection may apply to endangered or threatened species located on provincial lands where the Governor in Council orders as such. The provisions of SARA that contemplate this discretionary federal power are commonly referred to as the "safety net" provisions.

The Alberta Piping Plover Recovery Team, Alberta Piping Plover Recovery Plan, 2010 - 2020 (Edmonton: Alberta Sustainable Resource Development, 2010) at 9-10.

See Alberta Sustainable Resource Development, About Public Lands (Edmonton: Alberta Sustainable Resource Development, 1997), online: Alberta Sustainable Resource Development <http://www.srd. alberta.ca/FormsOnlineServices/documents/PublicLands-Sep-1997.pdf>. RSA 2000, c P-40.

Ibid, s 54(2).

Section 83 of $S A R A$, supra note 10, sets out general exceptions to these protections for authorized activities related to public safety, health, national security, or under the permitting provisions of $S A R A$ in sections 73,74 , or 78 .

Ibid, $\mathrm{s} 97$.

RSC 1985, c F-14.

SC 1994, c 22.

SC 2000, c 32.

RSC 1985, c W-9. 
The majority of protection for species at risk under SARA comes in the form of "no take" and "no harm to critical habitat" provisions. Section 32(1) states that "[n]o person shall kill, harm, harass, capture or take an individual of a wildlife species that is listed as an extirpated species, an endangered species or a threatened species." Section 33 of the Act prohibits a person from damaging or destroying the residence of an individual member of an endangered or threatened species. ${ }^{74}$ Section $58(1)$ of $S A R A$ prohibits a person from destroying any part of the critical habitat of an endangered or threatened species. These protections generally apply to fish, migratory birds, and any endangered or threatened species located on federal lands.

There is no provision in $S A R A$ that prohibits a federal authority from approving or authorizing an activity that will jeopardize the existence of a species at risk or adversely harm its habitat. Section 77 of the Act does, however, require federal authorities to consider mitigation of the impact in issuing a project authorization and to ensure all feasible measures to reduce the harm to a critical habitat are taken. ${ }^{75}$ Where federal approval is granted, the recipient who undertakes the approved activity will still be subject to prohibitions in $S A R A$, including those set out in sections 32,33 , and 58, subject to having specific authorization under section 73 to harm an endangered or threatened species, its habitat, or the residence of an individual member of such species. ${ }^{76}$

The prohibitions against destroying critical habitat are predicated upon the identification of such habitat in a recovery strategy prepared by the Minister in accordance with section 41 of SARA. Section 37(1) of the Act requires the Minister to prepare a recovery strategy for an extirpated, endangered, or threatened species. Section 41(1)(c) requires the Minister to identify critical habitat in the recovery strategy. The extent of this obligation has been subject to judicial interpretation in Alberta Wilderness Association v. Canada (Minister of Environment) ${ }^{77}$ concerning the sage grouse populations in Alberta, and in Environmental Defence Canada v. Canada (Minister of Fisheries and Oceans), ${ }^{78}$ concerning the Nooksack dace in British Columbia. It is important to note that "critical habitat" is defined in section 2(1) of $S A R A$ as the "habitat that is necessary for the survival or recovery of a listed wildlife species and that is identified as the species' critical habitat in the recovery strategy or in an action plan for the species." The provisions in SARA applicable to critical habitat protection only apply to habitat identified in a recovery strategy. Section 42(1) of the Act requires the Minister to publish a proposed recovery strategy within one year of listing for an endangered species and within two years of listing for a threatened species.

Section 58(2) of $S A R A$ requires the Minister to designate critical habitat identified in a recovery strategy that is located in a federally protected area, such as a national park. Outside

Section 2(1) of SARA defines "residence" as a "dwelling-place, such as a den, nest or other similar area or place, that is occupied or habitually occupied by one or more individuals during all or part of their life cycles, including breeding, rearing, staging, wintering, feeding or hibernating."

75 Similarly, section 79 of $S A R A$ requires notification of such harm in an environmental assessment conducted under the Canadian Environmental Assessment Act, SC 1992, c 37, and that measures be undertaken to mitigate adverse impacts on species at risk.

The suggestion here is simply that $S A R A$ would provide more effective legal protection if it prohibited federal authorities from authorizing projects likely to adversely impact listed species or their habitat. 2009 FC 710, 45 CELR (3d) 48. For commentary on this decision see Nigel Bankes, "Is SARA growing teeth?" (28 July 2009), online: ABlawg.ca <http://ablawg.ca/2009/07/28/is-sara-growing-teeth/>. 2009 FC 131, [2009] FCJ no $182(\mathrm{QL})$. 
of these areas, sections 58(4) and 58(5) of the Act require the Minister to indicate how federal laws protect critical habitat identified in a recovery strategy or, alternatively, issue a protection order to protect critical habitat that is not otherwise protected by federal laws. These provisions have received judicial interpretation by the Federal Court of Appeal.

In Georgia Strait Alliance v. Canada (Minister of Fisheries and Oceans), ${ }^{79}$ the Federal Court of Appeal provided two key rulings concerning section 58 of SARA. First, the Court ruled that habitat protection in section 58 means something more than "habitat management." ${ }^{80}$ Second, the Court ruled that section 58 is intended to protect critical habitat from destruction by any means, including activities authorized by federal officials. Therefore, critical habitat protection provided by section 58 of the Act means legally enforceable protection not subject to executive discretion. ${ }^{81}$ In this case, the Court held that the Minister erred in law by relying on section 35 of the Fisheries Act as critical habitat protection for the at risk killer whale populations in the coastal waters of British Columbia. ${ }^{82}$ The relevant portions of section 35 read as follows:

(1) No person shall carry on any work or undertaking that results in the harmful alteration, disruption or destruction of fish habitat.

(2) No person contravenes subsection (1) by causing the alteration, disruption or destruction of fish habitat by any means or under any conditions authorized by the Minister or under regulations made by the Governor in Council under this Act. ${ }^{83}$

The Court ruled the Minister could not rely on section 35 of the Fisheries Act as critical habitat protection for the purpose of section 58 of SARA because the protection in section 35(1) was discretionary. ${ }^{84}$

The critical habitat designations and orders issued under sections 58(4) and 58(5) of SARA engage the prohibition in section 58(1) of the Act against destroying the critical habitat of an endangered or threatened species. The application of section 58(1) is difficult to follow, but in essence is as follows. Section 58(1) applies to critical habitat located on federal lands and all the critical habitat of fish, and the Minister has a legal obligation to either: (1) issue an order prohibiting the destruction of such critical habitat; or (2) issue a statement describing how such critical habitat is legally protected in accordance with Georgia Strait. Section 58(1) only applies to the critical habitat of migratory birds on non-federal lands to the extent ordered by the Governor in Council on the recommendation by the Minister. ${ }^{85}$

2012 FCA 40, 65 CELR (3d) 28, aff'g 2010 FC 1233, 379 FTR 183 [Georgia Strait]. For additional commentary on this decision see Nigel Bankes, "Federal Court of Appeal confirms that a SARA protection statement must offer the critical habitat of a listed species real legal and non-discretionary protection" (23 February 2012), online: ABlawg.ca <http://ablawg.ca/2012/02/23/federal-court-ofappeal-confirms-that-a-sara-protection-statement-must-offer-the-critical-habitat-of-a-listed-species-reallegal-and-non-discretionary-protection/>.

Georgia Strait, ibid at para 114.

Ibid at paras $117-25$.

Ibid at para 130.

Fisheries Act, supra note 70.

Georgia Strait, supra note 79 at para 130.

Section 58(5.1) of $S A R A$ states the critical habitat protection in section 58(1) only applies to migratory bird habitat designated by order of the Governor in Council, but the drafting is not entirely clear in this regard. The relevant portions of section 58(5.1) read as follows: "[W]ith respect to the critical habitat of a species of bird that is a migratory bird protected by the Migratory Birds Convention Act, 1994 that 
Section 80(1) of SARA provides the Governor in Council with the discretionary power, on the recommendation of the Minister, to issue an emergency order to protect a listed species. Section 80(2), together with section 81 of the Act, requires the Minister to make such a recommendation where he or she forms the opinion that the species faces imminent threats to its survival or recovery, and is of the opinion that federal legal protection is not otherwise provided. Section 80(4) of the Act sets out what an emergency protection order may include. The legislated parameters of an emergency order vary depending on the same considerations used throughout $S A R A$ : an emergency order has widest application to fish, migratory birds, and other species located on federal lands.

In September 2010, several First Nations, together with the Alberta Wilderness Association, applied to the Federal Court for an order requiring the federal Minister of the Environment to exercise the emergency protection powers under $S A R A$ for the benefit of boreal caribou populations in northern Alberta. ${ }^{86}$ The consensus of scientific opinion, including that of COSEWIC and the Alberta Caribou Recovery Team, was that Alberta northern caribou populations were in significant decline, were at non-sustainable population levels, and were at risk of extirpation. ${ }^{87}$ Notwithstanding this evidence, the federal Minister of the Environment formed the opinion that the woodland caribou did not face an imminent threat to its survival or recovery largely on the basis that populations in eastern Canada were healthy. ${ }^{88}$ The Minister, thus, declined to make a recommendation that the Governor in Council issue an emergency protection order for the boreal caribou under section 80(1) of $S A R A$. The Federal Court ruled that the Minister erred in law by providing inadequate reasons to explain how the Minister's decision correlated with the scientific evidence on the declining status of boreal caribou populations in Alberta. ${ }^{89}$ The Minister subsequently reissued his decision not to recommend emergency protection. ${ }^{90}$

\section{Concluding Thoughts on Legal Protection: THE SARA SAFETY NET}

The Wildlife Act provides minimal legal protection to an endangered species, such that the Alberta government purports to meet its obligation to effectively protect species at risk using only discretionary powers and policy. The legal protections under $S A R A$ are more extensive, but their application is generally limited to fish, migratory birds, and other species located

is not on federal land ... subsection (1) applies only to those portions of the critical habitat that are habitat to which that Act applies and that the Governor in Council may, by order, specify" (SARA, supra note 10).

86 See Adam v Canada (Minister of Environment), 2011 FC 962, 395 FTR 48 at para 2 [Adam].

87 See generally Cichowski, supra note 58; COSEWIC, Assessment and Update Status Report on the Woodland Caribou Rangifer taradus caribou in Canada (Ottawa: Environment Canada, 2002), online: Free Grassy Narrows <http://freegrassy.org/wp-content/uploads/2010/03/cosewic woodland_caribou report thomas Gray 2002.pdf >; Environment Canada, Scientific Assessment to Inform the Identification of Critical Habitat for Woodland Caribou (Rangifer tarandus caribou), Boreal Population, in Canada: 2011 Update (Ottawa: Environment Canada, 2011), online: Environment Canada $<\mathrm{http}: / / \mathrm{ec} . g c . c a / d a t a$ donnees/STB-DGST/001/Boreal_Caribou_2011_Scientific_Assessment_Mapping_Methods_ Appendix_-_ENGLISH.pdf>.

Adam, suprā note 86 at para 3.

Ibid at paras 58-69.

See "Alberta's woodland caribou: Ecojustice is going back to court to challenge federal Environment Minister Peter Kent's stance on emergency protection for northeastern Alberta's caribou" (23 February 2012), online: Ecojustice $<$ http://www.ecojustice.ca/cases/woodland-caribou>. 
on federal lands. ${ }^{91}$ It follows that there is minimal legal protection for endangered species, other than fish or migratory birds, which are located on Alberta lands. In the case of migratory birds, the critical habitat protections of $S A R A$ only apply on provincial lands if so ordered by the Governor in Council, although section 5.1 of the Migratory Birds Convention Act, 1994 does purport to protect migratory bird habitat located in a province. ${ }^{92}$ Therefore, full legal protection for species at risk in Alberta - that is, non-discretionary legal prohibitions against killing an individual of an endangered species or harming its critical habitat - essentially extends only to fish and those species located in the national parks, federal migratory bird sanctuaries, and national wildlife areas.

However, on the recommendation of the Minister, the Governor in Council may order that protections to endangered species and their critical habitat provided by $S A R A$ apply to provincial lands. ${ }^{93}$ This is the so-called federal "safety net" power in $S A R A .{ }^{94}$ The exercise of this power would result in the application of the protections in sections 32,33 , and 58 to all endangered or threatened species in a province, and would thereby significantly extend the reach of $S A R A$ beyond federal species and federal lands in Alberta.

The application of these powers is predicated on a recommendation by the Minister to the Governor in Council. While generally a discretionary decision for the Minister, SARA does require the Minister to recommend the application of safety net provisions if he or she is of the opinion that provincial laws are not effective. For example, section 34(3) of SARA states that the Minister must make this recommendation if he or she is of the opinion that the laws of the province do not effectively protect an endangered or threatened species or its residence. Similarly with respect to critical habitat, section 61(4) of the Act requires the Minister to make this recommendation if he or she is of the opinion that there is no federal law or federal-provincial agreement that protects the habitat and that the laws of the province do not effectively protect the habitat.

In the authors' opinion, the provisions of the Wildlife Act do not effectively protect species at risk or their critical habitat in Alberta. There is minimal legal protection for an individual endangered animal, no legal protection for an endangered plant, and no legal protection for critical habitat. Alberta's strategy of using discretionary powers to protect species at risk renders the province vulnerable to the implementation of these safety net powers. However, the history of federal-provincial relations in environmental management suggests that the application of the safety net provisions in $S A R A$ to Alberta lands is somewhat of a remote possibility.

Section 60 of SARA empowers the Governor in Council, on the recommendation of the Minister, to prohibit the destruction of critical habitat of non-federal endangered or threatened species (in other words, species listed as such by a province or territory) located on federal lands.

92 Supra note 71, s 5.1(1): "No person or vessel shall deposit a substance that is harmful to migratory birds, or permit such a substance to be deposited, in waters or an area frequented by migratory birds or in a place from which the substance may enter such waters or such an area." While there have been many successful prosecutions under section 5.1, the effectiveness of this section as habitat protection is questionable. For some discussion on this point see Shaun Fluker, " $R v$ Syncrude Canada: A Clash of Bitumen and Birds," Case Comment (2011) 49:1 Alta L Rev 237. SARA, supra note 10, ss 34(2), 58(5.1), 61(2), 80(1).

For more discussion of the safety net provisions of SARA, see Stéphane Wojciechowski et al, "SARA's Safety Net Provisions and the Effectiveness of Species at Risk Protection on Non-Federal Lands" (2011) 22:3 J Envtl L \& Prac 203. 
Canadian scholars have extensively studied the exercise of jurisdiction by the federal government over environmental issues on provincial lands, and the research demonstrates that the federal government is generally reluctant to exercise its powers, even in the face of provincial ineffectiveness. ${ }^{95}$ For example, Andrew Thompson examined the 1970 Canada Water Act ${ }^{96}$ which included unilateral federal powers to regulate water quality in interprovincial waters. ${ }^{97}$ He notes the federal government did not exercise these powers, despite the absence of provincial action. This study, in combination with several additional case studies, led Thompson to conclude that the federal government generally defers to the provinces on environmental matters located on provincial lands:

Despite strong public pressure concerning individual environmental issues, the federal government has steadfastly refused to extend its jurisdiction to include environmental matters that are essentially contained within provincial boundaries even where there have been extra-provincial spillovers, as in the cases of air and water pollution. ${ }^{98}$

F.L. Morton describes Canadian environmental policy as "federal in theory but often provincial in practice." " Likewise, J. Owen Saunders refers to "the principle of a preeminent provincial role" on Canadian environmental policy. ${ }^{100}$

The research suggests a principal reason for federal reluctance is the significant hostility from provincial governments in response to federal environmental initiatives with implications on natural resource development. For example, Kathryn Harrison notes that British Columbia, Alberta, Ontario, and Quebec strongly opposed the unilateral federal powers in the 1970 Canada Water Act. ${ }^{101}$ In response, the federal government assured the provinces it would not exercise its unilateral powers in the legislation. ${ }^{102}$ Harrison describes provincial opposition during the 1990s to federal powers under the Canadian Environmental Assessment $A c t^{103}$ as an "unprecedented degree of consensus." "104 The Alberta government is often at the forefront of opposition to federal environmental powers in the name of defending provincial jurisdiction over natural resources. ${ }^{105}$

See e.g. Andrew R Thompson, Environmental Regulation in Canada: An Assessment of the Regulatory Process (Vancouver: Westwater Research Centre, 1980) at 19-26; Alastair R Lucas, "Harmonization of Federal and Provincial Environmental Policies: The Changing Legal and Policy Framework" in J Owen Saunders, ed, Managing Natural Resources in a Federal State: Essays from the Second Banff Conference on Natural Resources Law (Toronto: Carswell, 1986) 33; G Bruce Doern \& Thomas Conway, The Greening of Canada: Federal Institutions and Decisions (Toronto: University of Toronto Press, 1994); FL Morton, "The Constitutional Division of Powers with Respect to the Environment in Canada" in Kenneth M Holland, FL Morton \& Brian Galligan, eds, Federalism and the Environment: Environmental Policymaking in Australia, Canada, and the United States (Westport, CT: Greenwood Press, 1996) 37; Kathryn Harrison, Passing the Buck: Federalism and Canadian Environmental Policy (Vancouver: UBC Press, 1996).

$96 \quad$ RSC 1970, c 5 (1st Supp).

97 Harrison notes the Canada Water Act as the first instance of broad federal statutory power over environmental issues: Harrison, supra note 95 at 64.

Thompson, supra note 95 at 19. Harrison echoes this conclusion (Harrison, ibid at 54). Morton, supra note 95 at 50.

J Owen Saunders, "Good Federalism, Bad Federalism: Managing our Natural Resources" in Managing Natural Resources in a Federal State, supra note 95, ix at xii.

Harrison, supra note 95 at 74-75.

Ibid at 75 .

SC 1992 , c 37.

Harrison, supra note 95 at 136.

For an Alberta perspective on opposition to the federal environmental assessment policies see Susan Blackman et al, "The Evolution of Federal/Provincial Relations in Natural Resources Management" (1994) 32:3 Alta L Rev 511. See also generally Harrison, supra note 95. 
History suggests it is very unlikely that the federal government would choose to exercise its unilateral power to apply $S A R A$ on provincial lands, particularly in Alberta where the provincial government aggressively opposes the exercise of federal environmental powers. This conclusion is magnified even further by the fact that Alberta has expressly stated that one purpose of its species at risk strategy is to defend against the application of SARA to provincial lands. ${ }^{106}$

\section{Conclusion}

Species at risk legislation is a relatively new development in the law, and we are just starting to observe the impact of these legal rules. So it is, perhaps, somewhat premature to make definitive statements on the effectiveness of species at risk legislation in achieving its purpose of preventing species extinction and restoring those species on the brink of extinction. Nevertheless, there is a sufficient basis upon which to draw comparisons between laws governing endangered species, as this article has attempted to do in sketching out the basics of species at risk legislation in Alberta.

Protection for species at risk under the Wildlife Act is almost entirely within the discretion of the provincial Minister of Environment and Sustainable Resource Development. This should not be confused with legal protection. There is no legal process governing how a wildlife species becomes listed as endangered, and, thus, the listing process is entirely nontransparent and unpredictable. This is less problematic than it might otherwise be, given the few legal implications that result from an endangered species listing under the Wildlife Act. There is no legal obligation to plan for the recovery of an endangered species. There is no direct prohibition against taking (or killing) an individual member of an endangered species. There is no protection for the critical habitat of an endangered species. The Wildlife Act, therefore, does not provide effective legal protection for an endangered species.

Legal protection for species at risk in Alberta under $S A R A$ is less discretionary and more transparent than that provided under the Wildlife Act. The listing process is transparent and relatively more predictable. There is a legal obligation on federal officials to plan for the recovery of listed endangered or threatened species, including any listed species located on Alberta lands. However, the effectiveness of recovery efforts and legal protection under $S A R A$ for species at risk in Alberta is significantly compromised by the limited application of $S A R A$ to fish, migratory birds (to a lesser extent than fish), and other species located on federal lands in the province, such as a national park. The critical habitat of most terrestrial species at risk located in southern latitudes of Canada is located on provincial lands. Absent an agreement with provincial officials or an order by the Governor in Council to regulate activity on provincial lands, $S A R A$ offers little assurance of legal protection for endangered species and their habitat in Alberta. 
The Wildlife Act provides almost no legal protection to endangered species in Alberta. $S A R A$ offers substantive protection, but is of limited application. The history of federalAlberta relations on environmental matters suggests an agreement or order to enable the application of SARA to provincial lands is a remote possibility. Accordingly, the existing legal framework governing species at risk in Alberta gives the perception of legal protection for endangered species that does not actually exist in Alberta. 